\title{
中越地震と17豪雪の複合災害（速報） \\ The Advance Report of Snow Hazard and Chu-etsu Eathquake Coupling in 2005 Winter.
}

上 村 靖 司*

Seiji Kamimura

\section{1.はじめに}

2004年10月23日に発生した「新潟県中越地震」は, 山村豪雪地域における積雪期直前の大規模地震とい う特殊性から，冬の豪雪との複合災害発生が強く懸 念されていた

12月22日に降り始めた雪は, 気象庁の長期予報, かまきりの予想 ${ }^{21}$, 被災地域住民の期待を裹切り， 19年ぶりの豪雪を被災地にもたらした。

まだ冬は続いており, 雪害発生の状況が確定した わけではないが，深刻な事態となっていることから， 雪害発生に対する中越地震との関連性, すなわち “地震と豪雪の複合災害”に特に注目しながら，速 報として概況を報告する。

\section{2. 今冬の降積雪}

今冬の豪雪を特徵付けるのは, 1 月 7 日〜 13日と 1月30日〜 2 月 1 日の 2 度の集中的な豪雪である。 気象庁 $\mathrm{AMeDAS}$ 観測地点 3 箇所 (長岡, 小出, 十 日町）の最深積雪の日別デー夕（24時測定）を平年 值と比較して図 1 に示す。震災から 2 ケ月目の12月 22日に各地で降り出した雪は根雪となり，断続的で 集中的な降雪によって，1月中旬までに平年値を超 えた。1月10日前後の集中的な豪雪は魚沼市小出地 域で 5 日間積雪深差 $148 \mathrm{~cm} ， 1$ 月末の集中豪雪では 十日町で 3 日間積雪深差 $143 \mathrm{~cm}$ を記録した。長岡 でも 1 月30日24時から 2 月 1 日24時までの48時間で 積雪深が $117 \mathrm{~cm}$ 增すなど, 各地で記録的な豪雪と なった。

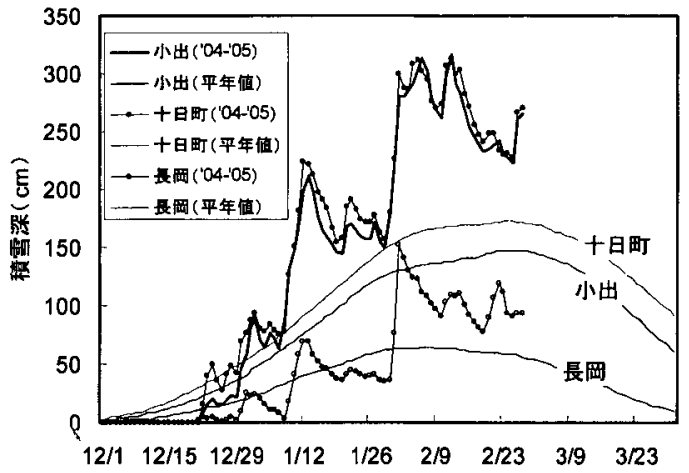

図 1 代表地点の積雪深（'04.12-'05.3）

図 1 に示すように, 平年値では十日町の方が小出 よりも $20 \mathrm{~cm} \sim 30 \mathrm{~cm}$ ほど多いが，今冬はほぼ同じ積 雪深で推移している点にも注意が必要で, 後ほど述 ベる人身雪害の発生状況にも関係する。

\section{3. 道路の除雪, 消雪施設等}

11月 2 日に発足した“新潟県中越地震・雪氷災害 調査検討委員会”による現地踏査が始まった 11 月 6 日頃から, 国や新潟県の担当部署において, 地震後 の雪害発生への早急な対応が必要であると言う認識 が共通のものとなり, 地下水散水式融雪装置（以降 単に消雪パイプと表記する) の損傷状沉調查等が一 斉に始まる。11月22日には県道の除雪計画が発表さ れ，消雪施設の復旧作業が本格化した。県道の消雪 パイプについては，12月末までに応急復旧が完了し たが，市町村道では雪が降ってから復旧工事が始まっ たという場所も少なくない。小千谷市時水の事例の

* 長岡技術科学大学 機械系 講師 
ように，応急的な復旧工事は行われたものの、コン クリート舖装とアスファルト舗装の間の割れ目に散 水が流れ込み、消雪パイプとしての役割を果たさな かった場所もある (写真 1 )。破損の激しい部分を, プレキャスト式の散水ユニットに置き換える応急復 旧が行われた場所で, 埋め戻しのアスファルト被覆 が不十分で機能不全となっている場所もあった。

流雪溝について見ると, 小千谷市の本町通で河川 からの揚水が供給されず，屋根から下ろした雪の処 理がおいつかなくなり, もともと狭い商店街の道路 の幅員がさらに狭まり激しい橴滞が発生したり，住 民が雪処理に苦慮したり,ということが繰り返し報

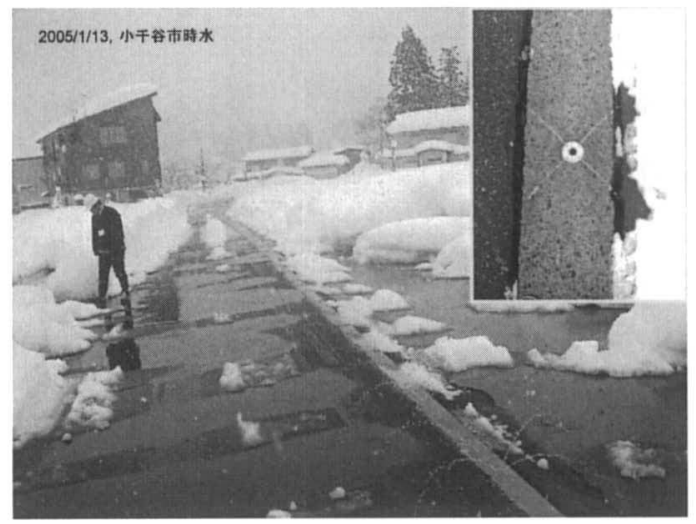

写真 1 消雪施設の障害：散水が割れ目に流れ込 み消雪パイプの役割を果たさず， 2 車線道路が 1 車線しか通行できなくなっている（2005年 1 月 15 日, 小千谷市時水)。

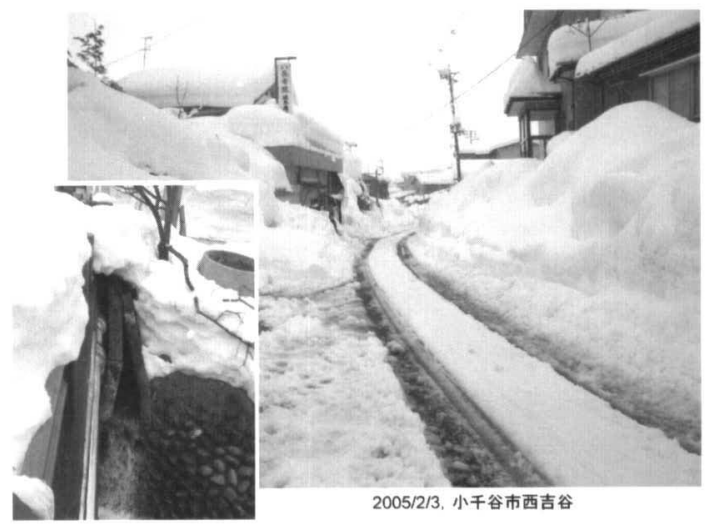

写真 2 流雪溝の流末部分の損傷により, 雪を流さ ないよう行政指導された路線。2 車線道路の両脇 に屋根からおろした雪が積みあがり 1 車線しか通 れなくなっている（2005/2/3，小千谷市西吉谷）。
道された。小千谷市西吉谷地区や同上片貝地区など, 自然河川の流水を使った流雪溝において, 流路や流 末が破壊され，閉塞による溢水の懸念から，行政が 使用自肃を要請するケースもあった（写真 2 )。例 年よりも水量が少ない，という住民の声も何籄所か で聞かれた。小千谷市の船岡町でも同様の不便が生 じていたようであり，損傷住宅の倒壞への不安から 雪下ろしが頻繁に行われ，例年以上に道路に雪が排 出され，その雪を輸送する流雪溝が十分に機能せず， 結果, 次の雪下ろしができないという悪循環を生ん だ。

\section{4. 建物の被害}

行政の所管する道路網の復旧に比して, 遅々とし て進まなかったのが, 住宅の復旧である。12月初旬 には，ほとんどの地域で仮設住宅が完成し，住民を 車庫やテントでの暮らしから解放したが, 復旧不可 能と判断された家屋の解体撤去, 復旧可能ではある が修理には大規模な工事が必要で，到底雪が降るま での短い期間では間に合わないという家屋，屋根の 補修や応急の補強など最低限の冬備えすら大工の不 足で間に合わないという家屋が相当数残された。

川口町では雪が降るまでに, 隣家等への危険を及 ぼす可能性のある建物を中心に150棟を引き倒した。 それでも，間に合わず放置された住宅や，避難勧告 が解除されることなく冬を迎えた集落もあった。例 えば小千谷市では，12集落で避難勧告が解除される ことなく冬を過ごしている。写真 3 は, 小千谷市塩 谷地区の家屋であり，2 月 9 日時点ではまだ残って いたが，2月24日に雪の荷重による倒壊を確認した

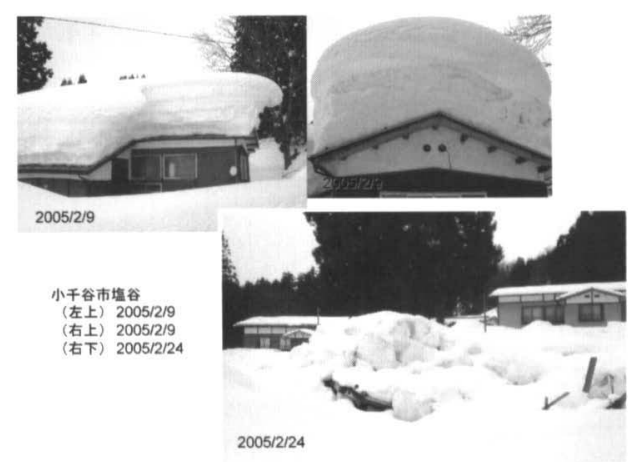

写真 3 雪荷重で倒壊した家屋 
ものである。新潟県内全域で, 2 月28日現在134棟が 倒壊した。これは住家47棟を含む。47棟の内訳は, 小千谷市 22 棟, 栃尾市 9 棟, 川口町 8 棟, 長岡市 5 棟, 魚沼市 2 棟, 川西町 1 棟である。小千谷市 22 棟 のうち半数の11棟は, 避難勧告が解除されず, かつ, 道路除雪が行われないため, 住民が雪下ろしに入る ことのできない塩谷地区である。

なお，以上の数字には全村避難が続く山古志村の 数值は入っていない。少なく見積もつても数十棟規 模での倒壊が見込まれている。

倒壊には至らずとも, 雪の重みで軒先が折られる などの部分損壊は, 各地で相当数見られる (写真 4$)$ 。 春に解体撤去を決めている家で, 解体後の廃棄物収 集の際に，分別されているかいないかで，処理費用 が大きく変わることから, 高齢者が懸命の除雪作業 をする様子も各地で見られた（写真 5 )。数十万円

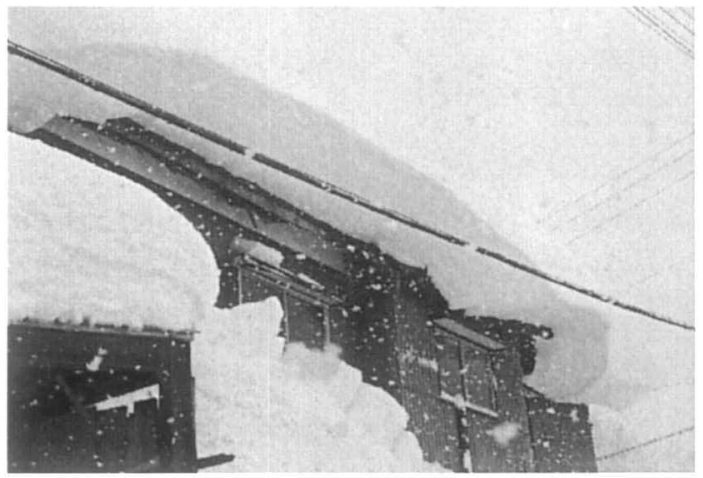

写真 4 巨大な雪庇が発達し軒先が折れた家屋 (2005/2/3, 川口町田麦山)

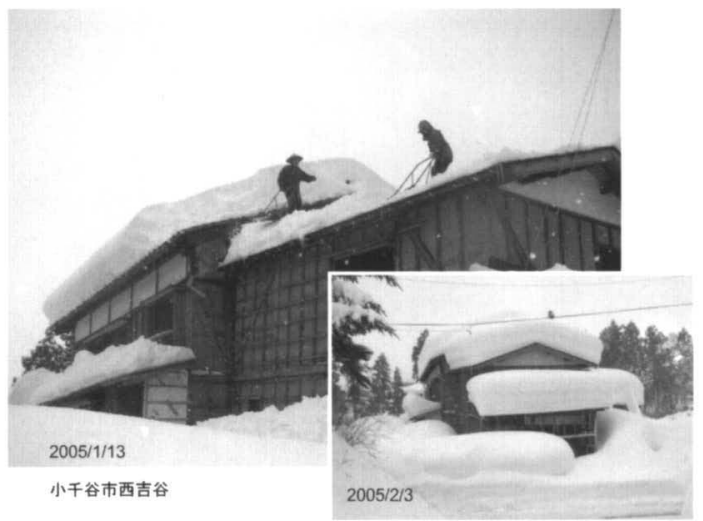

写真 5 春に解体を決めている家屋の雪下ろしをす る老夫婦。1 月末の豪雪を経て, 再び屋根上には $1 \mathrm{~m}$ 以上の積雪が (小千谷市西吉谷)。
の処理費と除雪業者委託費を浮かせるために，ぐら つく家の屋根に上がっていた。こういつた命に関わ る問題こそ，最優先で公的支援がなされるべきであ り，生活再建に対して先行きが不透明な中で，少し でも将来の不安を軽減できるような“血の通った公 的支援”ができないものだろうか。

\section{5 . 除雪中の事故}

2005 年 2 月 28 日現在，雪による人的被害は，死者 23 名, 死傷者 147 名である。 2 月下旬に入り，県の まとめる資料の名称が「雪下ろし等による死者・負 傷者一覧表」から「雪による被害（人的）状況」へ と変わった。雪下ろし作業に限らず，人身雪害が多 様化していることを暗に示している。図 2 は，被害 者数の累積値を, 今冬事故件数の多い魚沼市に护け る積雪深と比較して示している。前述の，1月10日 前後, 1 月末の 2 回の集中豪雪に呼応するように, 数日遅れで被害者数が急増していることが明らかに 読み取れる。

人身雪害の死傷リスク (SRI: Social Risk Index, 人口 10 万人当り 1 年間に事故に遭遇する確率）につ いて，1985年度冬季〜2003年度まで統計值と今冬の 被害状況を比較して表 1 に示す。人口数千人〜数万 人の小さな市町村が多いことから，新潟県の定める 地域別に集計し比較している。SRI で比較すると, 魚沼市で50を超え, 南魚沼, 十日町地域が続く。統 計值からの倍率で見た場合，県内全域で今冬 2 倍以

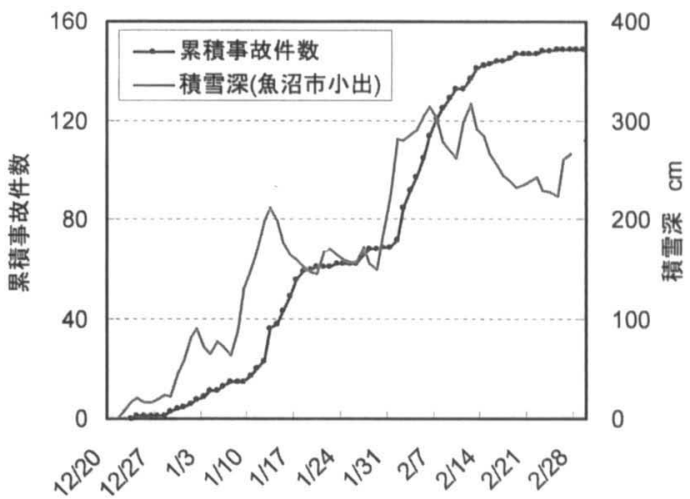

図 2 雪に関わる事故の発生状況 （新潟県危機管理防災課資料をグラフ化） 
上となっているが，魚沼市と長岡地域が約 4 倍と目 立ち, 震災被害の大きかつた小千谷地域でも 3 倍と なっている。事故の絶対数が少ないため, 数值の精 度は低いが，岩船，三条，柏崎といった，これまで に余り事故を経験していなかった地域での事故が多 くなっていることもわかる。これらの人身雪害の発

\section{表 1 新潟県内の地域別の事故遭遇リスク（速報値）}

\begin{tabular}{|c|c|c|c|c|c|}
\hline \multirow{2}{*}{ 地域*1 } & \multirow{2}{*}{$\begin{array}{c}\text { 人口 } \\
\text { (千人) }\end{array}$} & \multicolumn{2}{|c|}{ 04-05 冬季 } & \multirow{2}{*}{$\begin{array}{c}\begin{array}{c}85-03 \\
\text { 平均 }\end{array} \\
\text { SRI }^{* 2}\end{array}$} & \multirow[b]{2}{*}{ 倍率 } \\
\hline & & $\begin{array}{l}\text { 死傷 } \\
\text { 者数 }\end{array}$ & SRI $^{* 1}$ & & \\
\hline 新発田地域 & 153.9 & 2 & 1.3 & 0.5 & 2.5 \\
\hline 岩船地域 & 81.0 & 2 & 2.5 & 0.6 & 4.2 \\
\hline 三条地域 ${ }^{* 3}$ & 137.9 & 6 & 4.4 & 1.2 & 3.6 \\
\hline 長岡地域*3 & 311.9 & 38 & 12.2 & 2.9 & 4.1 \\
\hline 小千谷地域炎 4 & 54.7 & 11 & 20.1 & 6.7 & 3.0 \\
\hline 十日町地域 & 76.5 & 24 & 31.4 & 12.0 & 2.6 \\
\hline 魚沼市 & 43.9 & 23 & 52.4 & 13.7 & 3.8 \\
\hline 南魚沼地域 & 72.4 & 24 & 33.2 & 15.6 & 2.1 \\
\hline 柏崎地域 & 99.9 & 5 & 5.0 & 1.6 & 3.1 \\
\hline 上越地域 & 197.5 & 10 & 5.1 & 2.6 & 1.9 \\
\hline 新井地域 & 51.9 & 4 & 7.7 & 10.4 & 0.7 \\
\hline 糸魚川地域 & 153.9 & 1 & 1.9 & 2.1 & 0.9 \\
\hline
\end{tabular}

※ 1 SRI (Social Risk Index) は, 人口 10 万人当り 1 年間に 事故に遭遇した人数を表す。

※2 地域は, 「新潟県の広域市町村圈（平成16年 1 月 11 日現 在)」の区分による。

※3 三条地域は、これまでに人身雪害を経駚している三条市， 加茂市, 田上町, 栄恵町, 下田村を含む。

※4 県の定めた長岡地域から小千谷地域（小千谷市。小国町、 川口町, 山古志村）を分け, 残りを長岡地域とした。

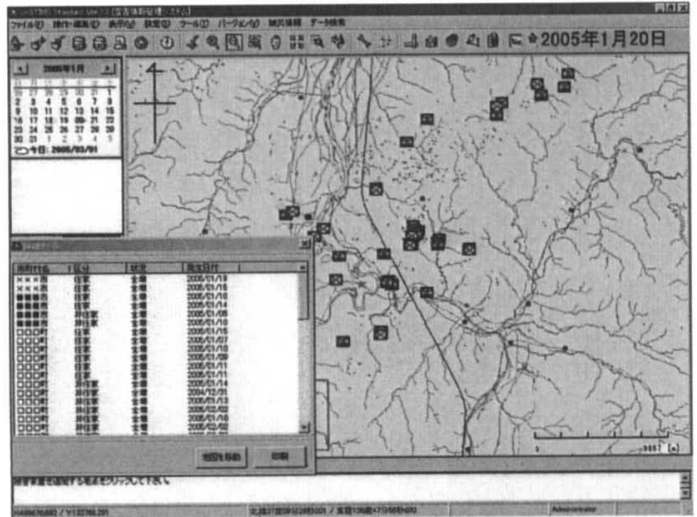

（a）雪荷重による倒壊家屋の分布
生の主因子は豪雪であるということは疑う余地がな いと思われるが, 1 月26日に発生した小千谷市の旅 館浴場の倒壊により 2 名の犠牲者が出た事故は, 地 震と豪雪の複合災害であったと見ることが妥当であ ると考えている。小千谷市時水で，玄関の雪庇落と し作業中に落雪事故に遭い男性が命を落とした事例 でも，仮設住宅を嫌い全壊認定の自宅に戻って過ご していたとのことで, 事故と地震との直接的因果関 係があったとは認めがたいが，豪雪地で生まれ育っ たベテランの精神的余裕を奪っていたと見ることが 不合理とは思わない。

死亡事故に限ってみると，屋根や梯子といった高 所からの転落が 6 名, 落雪が 5 名, 除雪機が 4 名, 水路転落が 3 名, 雪崩が 2 名, 発病が 3 名である。 その他, 県の統計に含まれない水路転落事故による 死者 3 名（児童 2 名，高齢者 1 名）も，記しておく べきであろう。全体的に多いのは間違いないが, 特 に, 落雪事故, 除雪機, 水路転落, 雪崩による死亡 事故が目立っている。速報值では，全国では74名が 雪に関わる事故で亡くなっているとされており ${ }^{3)}$ はや単なる“事故”では済まされない状態である。 あらためて豪雪が “災害”であることを訴えてゆか なければならない。

\section{6. 雪水防災研究への GIS の活用}

古くから言われているように雪害は，積分型災害 である。小さな災害が日々積み重なって，大きな災

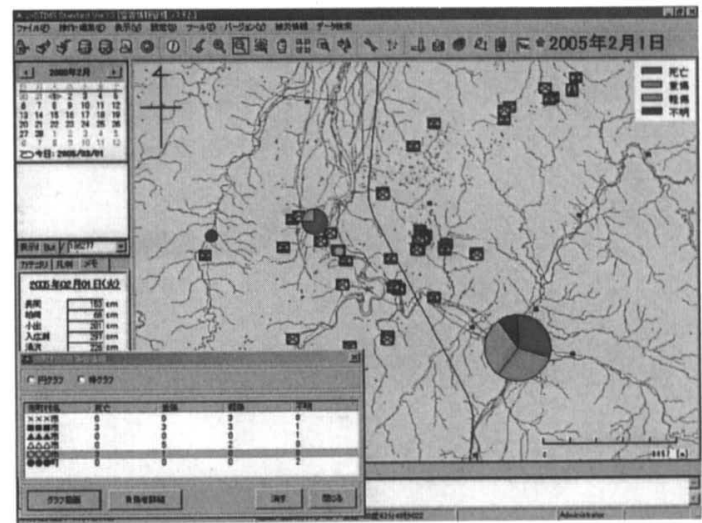

（b）雪に関わる人身事故の発生分布

図 3 雪害分析への時空間 GIS の活用事例 
害となる。上で述べた人身雪害の人数を見ればその ことに異論の余地はないであろう。主因子である降 積雪現象と社会的諸条件の関連を正しく理解して,

雪害低減策を提案してゆくには，単に雪害の空間分 布の把握だけでなく，その時間軸上で分析も不可欠 である。

その 1 つの方向として，「時空間 GIS」 ${ }^{4)}$ の導入 検討を始如（図 3 )。建物被害や人身雪害の記録 の蓄積, 分析ツールとしての活用を目的としてデー タ入力が行われて拉り，スノー・パトロール 等, 冬季の現地調査データも埋め込んでいく予定である。 また次の段階として、消雪パイプ，流雪溝といつた 防雪施設の震災被害状況ならびにその復旧過程の入 力も検討しており，災害復旧や復興，防災計画策定 のためのツールとしての有用性も期待しているとこ ろである。

\section{7. まとめ}

本報告では，新潟県に扮ける今冬の豪雪による被 害状況を, 中越地震との関連性に注目しながら，現 在までに把握されている内容を述べた。

道路に関しては，応急的とはいえ，2 月月の復旧 期間で, 最低限の冬備えは間に合った。当然，19年 ぶりの豪雪に太刀打ちできるレベルとは言いがたい が，最悪の状況は回避できたものと考えられる。建 物に関しては，冬までに補修や応急的な補強が間に 合わなかったために倒壊した家屋もあるが，多くの 場合は，復旧不能な建物の解体撤去が冬までに間に 合わなかったことによるものである。しかし，避難 指示・针告が解除されず雪下ろしもままならなかつ
た小千谷市塩谷地区などのように，守りたくとも守 りきれなかった住宅が含まれることも事実である。

雪に関わる人身事故等による死傷者数は, 統計か ら得られた平均的な数の 2 倍を越え，深刻な事態を もたらした。短絡的に地震との関連を論ずるべきで はないと考えるが，震災に関わる不安やストレスが 引き金となっていると思われる事例も少なくないこ とから, 今後十分な検証が必要である。また, 今冬 の豪雪は地震被災地新潟だけの問題でなく東北，北 海道にかけての広域的な問題であり，さらに言えば, 北米や中東などを含む，北半球全域にかけての問題 であるという認識が必要で, 改めて雪水防災研究の 緊急性, 重要性を思い知らされる冬となった。

\section{参考文献}

1) 上村靖司：中越地震後の雪水災害軽減のために -「新潟県中越地震・雪水災害調查検討委員会」 の発足と活動状況 (中間報告) - , 日本雪工学 会誌, Vol.21 No.1, pp3-7, 2005.1.

2 ）新潟県建設技術センター：冬を占う 平成16年 度予想版, 2004.10。

3 ) 須田正則 : 雪害の記録'04-05, http://blog.goo.ne.jp/chikibosai/

4) 栗原哲, 為国 孝敏, 坂本 登：時空間 GIS による地震被災状況データベースの構築と分析, 第33回土木学会関東支部技術研究発表会予稿集, 投稿中, 2005.3 .

$5 ）$ 上村靖司：冬の被災地見回り隊ースノー・パト ロールー，ゆきのまち通信 97 号, pp24-25, 2005.3. 